УДК УДК 130.2: 94(477)

DOI 10.35423/2078-8142.2020.2.1.03

М. М. Кисельов, доктор філософських наук, професор, провідний науковий співробітник Інституту філософії імені Г. С. Сковороди НАН Украӥни, м. Київ, Україна e-mail:nn1942@ukr.net ORCID: https://orcid.org/0000-0003-0427-1740

\title{
ІСТОРІЯ ТА ІСТОРИЧНА ПАМ'ЯТЬ: СФЕРИ ПЕРЕТИНУ
}

У статті подається компаративний аналіз феноменів історії та історичної пам'яті; аналізується проблема меж компетентності історичного методу як загальнонаукового. Наводиться ретроспекиія явища скепсису щзодо об'єктивності та обтрунтованості висновків історичної науки. Робиться висновок, щзо історична пам'ять є феноменом, корені якого сягають глибин антропогенезу, у зв'язку з чим заторкується вчення К.Юнга про архетипи. Досліджуються архетипічні витоки людської пам'яті, роль історичної пам'яті у формуванні національної ідентичності, модифікаиії та різновиди сприйняття «історичного минулого». Коментується явище політизаиії історичної пам'яті під впливом ідеологічної кон'юнктури. Проблема надзвичайно актуалізується тому, що нині політична кон'юнктура та система иінностей соиіуму багато в чому детермінують специфіку бачення, розуміння й тлумачення подій минулого. Особлива увага приділяється терміну «наиіональна історична пам'ять». Аргументується положення про некоректність радикального поділу начій на «політичні» та «етнічні». Розглядаються сучасні інтерпретаиії феноменів етноиентризму та презентизму в історичному контексті.

Ключові слова: історія, історична пам'ять, самоідентифікачія, форми історичної пам'яті, презентизм, етноцентризм, наиіональна політика. 
Проблеми порівняння семантики історії та історичної пам'яті завжди мали місце в історіографії. Нині вони набувають особливої актуальності. Загалом можна сказати, що саме історія і $\epsilon$ історичною пам'яттю людства. В доісторичний період і на самих початках історичної науки воно так і було. Батьком історії Цицерон назвав Геродота. Якщо у сповіщеннях Гомера домінувала, за свідченням Діогена Лаертського, мішанина побаченого й особисто почутого, то вже в Геродота спостереження були більш організованими і точними. Він задокументував власні міркування щодо причин і подій греко-персидських війн, створив суттєві етнографічні нариси, поклавши початок історичної географії, історії мореплавства та торгівлі. Як вважають фахівці, Геродоту можна вірити. Мета, яку він ставив перед собою, полягала в тому, щоб справи людські не були забуті і великі діяння «не втратили своєї слави». Послідовник Геродота Фукідід вже демонструє більш раціональне ставлення до дійсності і відмовляється в поясненні історичних подій втручанням надприродних сил. Фукідід звів історію з Олімпу і зробив iï історією людей, в якій шукав причини та наслідки подій минулого.

Як вважав Корнелій Тацит, грецька історіографія від самого свого зародження (Геродот, Фукідід, Полібій) мала художній характер (близькість до поезії і красномовництва) i, поряд із цим, у ній з'являлися елементи історичної критики, а також доволі розвинутий принцип історичної причинності. Історію завжди вважали навчителькою життя, скарбницею прикладів, які яскраво ілюструють доброчинність і пороки. Водночас, від самого початку висловлювалися сумніви в достовірності історичного матеріалу. Перш за все велику роль тут відіграють «людський чинник» та явище «презентизму». Корнелій Тацит писав про попередників: «Про справи народу римського, щасливих і нещасних, писали прославлені історики: не було нестатку у блискучих талантах і для оповіді про часи Августа, поки їх не відвернуло від цього всезростаюче плазування перед ним. Діяння Тіберія і Гая, а також Клавдія і Нерона, поки вони були всесильні, зі страху перед ними були викладені брехливо, а коли їх не стало - під впливом залишеної ними ще свіжої ненависті» [20, с. 7]. Пізніше Лукіан із Самосати стверджував, що «більшість істориків, нехтуючи описом подій, зупиняються на вихвалянні начальників і полководців, підносячи своїх до небес, а 
ворожих незмірно принижуючи» [Цит. за: 23, с. 23]. Так було і так $\epsilon$ майже до сьогодні. Згадаймо культ Сталіна. К. Тацит був переконаний е тому, що історик має бути максимально об'єктивним. Його відомий принцип - «без гніву і пристрастей». «Тому хто вирішить непохитно триматися істини, слід вести оповідання, не піддаючись любові і не знати ненависті [20, с. 385]. Із цим погоджувався і Лукіан: «Історик має бути безстрашним, непідкупним, незалежним другом вільного слова і істини» [Цит. за: 23, с. 57]. Але й до сьогодні історики дискутують - чи реально здійснити ці вимоги?

Плутарх взагалі не вважав себе істориком. «Ми пишемо не iсторії, а біографії, і не завжди в найславніших діяннях буває помітна добродійність або розпутність, але часто якийсь нікчемний вчинок, слово або жарт краще виявляє характер людини, ніж битва 3 десятками тисяч загиблих, величезні армії і осади міст... і нам буде дозволено більше заглиблюватися у виявлення душі, за допомогою їх зображувати життя кожного, залишивши іншим опис великих справ і битв» [15, с. 9-10]. Принцип Тацита описувати події без гніву і пристрасті був неприйнятним для Плутарха. Він засуджує Геродота, що той байдуже, без осуду повідомляє про ганебні вчинки своїх героїв.

Як тільки не визначали потім покликання історії та істориків: це свідок часів, світоч правди, життя пам'яті, наставниця життя, вісниця старовини (Цицерон); історик і мудрець, і очевидець, і суддя (Ф. Бекон). Люди нічому не навчались в історії і не діяли відповідно до уроків, які з неї випливають (Гегель). I водночас - хто не знає історії, той не розуміє теперішнього, а тим більше майбутнього. Історія не вчителька, а наглядачка, котра карає за незнання уроків. Вона вчить навіть тих, хто у неї не вчиться; вона їх провчає за невігластво і зневагу (В. Ключевський). Історики звикли вивчати сліди і забувають тих, хто їх залишив (Л. Гумільов). Історія - це зустріч людей у віках (М. Блок). Історія має глибокий зміст, проте він недоступний людському розумінню (К. Ясперс). Історик - посередник між минулим та майбутнім (А. Гуревич). Історія - постачальниця виховних взірців (М. Еліаде). Історія призначена для самопізнання людства (Р. Колінгвуд). Історія - це орієнтир найвищого порядку в людському житті (Й. Рузен). Міркувань щодо покли- 
кання історії та істориків можна навести безліч і майже кожне 3 них наголошує на чомусь важливому і суттєвому у цьому багатоликому феномені.

Як у філософії, так і в історії відбувся процес спеціалізації і формування окремих напрямів дослідження: історія природнича (Пліній Старший) і історія божественна (Августин Аврелій), історія всесвітня і історія регіональна (Йоганн Гердер), історія господарства, історії науки і техніки, філософії, культури, мистецтва, економіки тощо. Органічними фрагментами академічного корпусу історії стали історична хронологія і археологія, краєзнавство, фалеристика, нумізматика, джерелознавство, архівознавство тощо. Історичні дослідження від самого початку стимулювалися людською цікавістю і певними практичними і теоретичними цілями. 3'являються різні методологічні підходи до вивчення подій минулого: класичний, як історія війн, полководців, династій і матеріалістичний (К. Маркс), як поширення принципів матеріалізму на усвідомлення суспільних процесів у їх закономірному історичному розвитку. Історичний метод стає загальнонауковим і авторитетним в осягненні феноменів реальної дійсності, оскільки він сприяє розумінню суті проблеми і може бути застосованим для дослідження різних явищ та об'єктів природи і соціуму. I разом з тим виникає доволі мотивована критика деяких застосувань історичного методу (А. Шопенгауер, Ф. Ніцше, К. Поппер).

Так, зокрема, Карл Поппер вважав, що природничі та соціальні науки мають робити акцент на об'єктивність, безпосередній реальний досвід (протокольні судження), уникати полісемантики, метафоричності й емоційності, які є властивими соціогуманітарії. Критикував холізм як джерело «історицизму», який має претензію пояснювати і передбачати історичні події і явища соціального життя за допомогою інтуїції, для того, щоб усвідомити цілісний сенс історичного процесу. К. Поппер не сприймав концепцію «закономірності історичного розвитку» К. Маркса, не вважав за науковий висновок про «історичну необхідність». Критика його засновувалась на переконанні, що «тримаючись суворих логічних передумов, ми не можемо передрікати майбутній поступ історії» [16, с. 24]. Відзначимо, що доводячи «історизм» та «історицизм», історичний метод, заснований на вивченні виникнення, формуван- 
ня та розвитку об'єктів та явищ він не відкидав. Хоча і зазначав: «Перебіг історичного розвитку ніколи не піддасться теоретичному проектуванню, хоч би яким досконалим воно було, хоча не підлягає сумніву, що такі схеми можуть здійснювати вплив - разом 3 багатьма іншими, менш раціональними (чи навіть цілком ірраціональними) чинниками» [16, с. 69-70]. К. Поппер вважав «людський чинник» «непевним і свавільним елементом у соціальному житті», а намагання його контролювати - передумовою тиранії [16, с. 176]. Крім того, і до сьогодні даються взнаки рецидиви класичного уявлення про принципову несумісність знання про природу (номотетичного) та знання про суспільство (ідеографічного), обгрунтоване ще у працях О. Конта та Г. Ріккерта.

Марк Блок називав історію запізнілим гостем у сфері раціонального пізнання. «Історик відіграє роль слідчого, який намагається відновити картину злочину, при якому він не був присутнім» [7, с. 31]. Історичний матеріал завжди викликав сумніви в його науковій об'єктивності та упередженості, «невизначеності та конвенційності», тому потребував «інтерпретації та декодування» (Н. Яковенко). «Історик здавна видається певним суддею підземного царства, зобов'язаним вихваляти або таврувати загиблих героїв» [7, с. 79]. Спроби представників школи «Анналів», попри їх намагання інтегрувати в єдине концептуальне ціле всі контексти, що стосуються історії (географію, техніку, господарство тощо) і тим самим оновити «ремесло історика» не були надто успішними. Як слушно зазначає Л. Нагорна: «Нині, за умов, коли претензії на істинність в історичній науці розглядаються як нереалістичні, будь-які пояснювальні, аналітичні, а тим більше оціночні й екзегетичні теорії явно не в пошані» $[13$, с. 9].

Карл Ясперс був переконаним, що історична наука, вивчаючи людину, тим і відрізняється від природничих наук, що досліджують природу. Історія як людська реальність визначається перш за все духовними чинниками, серед яких найважливішими є чинники екзистенціального життя. «Лише історія людства в цілому може надати масштаб для осмислення того, що відбувається в теперішньому часі» [24, с. 29]. Принципово важливим періодом в історії, «віссю світової історії», він вважав «вісьовий час» (прибли- 
зно 3800 до 200 р. до н.е.; епіцентром цього періоду він вважав 500 р. до н.е.). Представниками цього періоду були Анахарсис у Великий Скіфії, Гомер і класики античної філософії - у Греції, Конфуцій і Лао-цзи - у Китаї, Гаутама (Будда) - в Індії, Гільгамеш - в Ассирії, Моисей - у Палестині та інші, незалежні один від одного титани духу, творці головних категорій мислення та засновники світових релігій. Саме під їх впливом людина почала усвідомлювати буття в цілому, власне буття і свої межі. «Перед нею відкривається страхіття світу і власна безпорадність. Стоячи над прірвою, вона ставить радикальні питання, вимагаючи звільнення i спасіння. Усвідомлюючи свої межі, вона ставить перед собою високі цілі, пізнає абсолютність в глибинах самосвідомості і в ясності трансцендентного світу» [24, с. 33]. Історія існує саме тому, що людина не вічна і принципово не $є$ завершеною. Завдяки історії вона має можливість відчути вічне. На землі ніколи не буде ідеального стану або досконалої людини. Саме тому «Ми прагнемо зрозуміти історію як дещо ціле, для того, щоб зрозуміти й себе. Історія $\epsilon$ для нас спогадом, про що ми не просто знаємо, в ньому корені нашого життя. Історія - основа, одного разу закладена, зв'язок $з$ якою ми зберігаємо, якщо хочемо не безслідно зникнути, а зробити свій внесок у буття людини» [24, с. 240]. Коли ж історичні дані використовуються для пропаганди, це сприймається як неправда про історію. Завдання осмислити історичний процес в цілому вимагає від нас усієї серйозності і відповідальності.

Історія і історична пам'ять не одне $і$ те саме, хоча й органічно пов'язані. Історія прагне точно та об'єктивно дослідити минулі події. Для того, щоб бути об'єктивним, історик має ментально відчувати себе в минулому, яке він досліджує. Водночас, це є нездійсненним. Г.-Г. Гадамер відзначає: «У дійсності мислити історично означає проробити ті зміни, які зазнають поняття минулих enox, коли ми самі починаємо мислити цими поняттями. Історичне мислення завжди і від самого початку включає в себе опосередкування цих понять 3 нашим власним мисленням. Намагатися виключити із тлумачення свої власні поняття не лише неможливо, а й безглуздо» [10, с. 462].

Історія від самого початку визначалась як опис, оповідь, пе- 
реказ про відоме минуле. Вона спиралась на письмові і матеріальні джерела. Відомо, що лише незначна кількість історичних фактів може бути достатньо перевіреною і підтвердженою. Минуле зникло, залишилися лише спогади (В. Дільтей). Сучасний погляд на минуле справді залежить від інтерпретації та декодування. Постійно дається взнаки об'єктивність історії та суб'єктивність історика (П. Рікер). Достатньо послатися на два альтернативні положення у сучасній історичній пам'яті росіян: концепція драматичного 300 річного «монголо-татарського ярма» і висновок євразійців «Ніякого монгольського «іга» не було. Був братський союз монгольського i російського народів» (Л. Гумільов) [Цит. за: 19, с. 179].

Відзначимо, що скепсис щодо об'єктивності й обгрунтованості положень історичної науки був завжди, але набув особливого поширення порівняно недавно. Н. Яковенко пише про зачарування історією у XIX ст.: «Це був той зоряний для історичної науки час, коли й самі історики, i їх шанувальники щиро вірили у здатність історика розшукати й описати ті «правдиві» факти, котрі відкриють сенс буття нації й послужать дороговказом до ії майбутнього. Саме на цій хвилі віри в очищувальну й напрямну силу «правди історії» у другій половині XIX - на початку XX ст. постають грандіозні за обсягом «великі національні історії» ї синкретичний виклад минулого тих чи інших країн і народів» (Й. Фіхте, Ж. Мішлє, О. Тьєрі, Ф. Шльосер, М. Костомаров та ін.) [23, с. 24]. Робін Колінгвуд вважав, що «наше так зване знання минулого $\epsilon$, отже, не знанням минулого як дійсно існуючого предмета і тому не $€$ істинним знанням; це - лише реконструкція ідеального предмета, здійснена заради інтересів пізнання теперішнього» [12, с. 503]. До того ж історія потрібна і необхідна не лише історикам. Аляйда Ассман слушно зауважує, що історія репрезентує лише минуле, а пам'ять переживається у сучасності. Проте «не існує історичного знання, яке водночас не було б і роботою пам'яті... Стрімка поляризація історії та пам'яті видається мені так само незадовільною, як і їхнє остаточне ототожнення» [2, с. 144-145].

Йорн Рузен обов'язком історика вважав репрезентувати минуле так, щоб воно стало значущим для сучасності й було інтегра- 
льною частиною культурного орієнтування життя. У метафоричному сенсі, доводив він, можна говорити про лікувальну й терапевтичну функцію історії. Минуле - «не заморожений фактаж». У цьому контексті доречно нагадати про явище презентизму (Present - теперішній час) в історіографії. Як напрям у методології історичного дослідження він остаточно сформувався в першій половині XX ст. Представники цього напряму (К. Беккер, Ч. Бард та ін.) заперечують класичне уявлення про історію як відображення об'єктивних явищ у минулому. На зміну старому минулому приходить минуле нове. Кожний епізод минулого слід розглядати крізь призму ідеологічних стосунків сучасності. Переконання, що кожний історичний етап має своє бачення минулого виникають ще в епоху Відродження. Нині політична кон'юнктура та система цінностей соціуму багато в чому детермінують специфіку бачення, розуміння й тлумачення подій минулого.

Проблематика історичної пам'яті у сучасній літературі набирає надзвичайної популярності. Значна увага приділяється таким iii різновидам, як колективна, культурна, соціальна, суспільна, етнічна, національна, виокремлюють також офіційну, народну, модерну, пострадянську тощо. Робляться скрупульозні спроби класифікувати означені різновиди, уточнити їх семантику, виявити способи їх взаємодії. Зазвичай зазначається, що той чи інший різновид пам'яті про минуле $є$ недостатньо визначеним. I робляться активні спроби визначити його досить повно - тобто ставиться абсолютно нездійсненне завдання. Відомий авторитет у цій проблематиці М. Хальбвакс вважав термін «історична пам'ять» невдалим. Я. Ассман піддає критиці термін «колективна пам'ять» за таку саму невизначеність. Дж. Олік взагалі вважає, що всі ці різновиди не $€$ операційними поняттями. У їхню семантику включаються «різносоціальні форми простори та практики». В Свропі пропагується «багато штучно створених форм ретроспекції». «І хоча ми можемо говорити про офіційну пам'ять, або народну пам'ять, про історичну, або письменну пам'ять, про публічну або приватну пам'ять, ми маємо пам'ятати, що і ці категорії та інститути, 3 якими вони пов'язані, постійно змінюються, серед них ведеться боротьба навколо пам'яті, котра впливає як на їх внутрішню, так і на зовнішню конфігурацію» [14, с. 48]. 
Варто проаналізувати деякі визначення варіацій пам'яті: $к y$ льтурна пам'ять трактується як особливий символічний спосіб передавання культурних смислів за допомогою знаків і символів; соцііальна - як колективна пам'ять, вписана у свідомість соціуму; $c y$ спільна - як система заходів перетворення та зберігання історичної інформації в суспільстві; комунікативна - як усна традиція, що виникає в процесі спілкування між людьми. Дж. Олік слушно рекомендує їх не змішувати i «не приймати офіційну пам'ять за колективну, а народну за автентичну. Жодна 3 них не може бути зрозумілою без вивчення інших форм пам'яті та інших елементів ситуації. До того ж не варто передбачати, що офіційна пам'ять як аспект політичного поля або народна пам'ять - постійні категорії» [14, с. 51]. Л. Нагорна зауважує, що термін «історична культура» потіснив терміни «історичне мислення», «історична свідомість», «історична пам'ять». Історична культура, яка нібито витісняє усі інші форми, є «система засобів репрезентації, що в ідеалі забезпечують дотримання певних етичних норм 3 метою консолідації соціуму на основі осмислення величезного історичного досвіду людських спільнот» $[13$, с. 11]. Як на мене, всі означені різновиди $є$ органічно пов'язаними пам'яттю про минуле, тобто формами саме «історичної пам'яті». Звичайно, історична пам'ять завжди знаходиться під пресом зацікавлених груп суспільства, ідеології та політики. Але ж цим небезпекам підпадають не лише пам'ять про минуле, а й сама історія. Презентизм як явище властивий і історичній пам'яті, і академічним історичним Анналам.

Історична пам'ять визначається як сукупність донаукових, наукових та інших знань та масових уявлень про спільне минуле. Вона $є$ неодмінною передумовою етнічної (національної) самоідентифікації. Насамперед, це успадкування минулого досвіду (традиції, пам'ятки, архіви, музеї, бібліотеки тощо). Історична пам'ять, як і будь-яка пам'ять, є здатною до містифікацій, що робить можливим ii деформації зусиллями зацікавлених (і навіть незацікавлених) осіб. Важливу роль тут відіграють і суто психологічні чинники інтерпретації історичного минулого. «Образи «справжніх» злодіїв самостверджуються в якості добропорядних громадян. Людям важко погодитися, що всі їх негаразди виникають 3 них самих. 
Простіше уявити себе жертвою найрозумніших і найковарніших злодіїв - це підвищує. Якщо людина не знаходить себе у сучасному, вона починає перелицьовувати минуле» [9, с. 56]. Крім того, на пам'ять та поведінку людини впливають стереотипи, сформовані під впливом традиції, закону та системи притаманних соціальному оточенню вартостей [23, с. 40]. Саме під впливом минулого кожній людині тією чи іншою мірою властивий консерватизм. Архимандрит Рафаїл (Карелін) кваліфікує його як духовний аристократизм. Чим більш доброчесною є людина, тим більше дорожить вона своїм минулим, своїми родовими звичаями, своїм прізвищем. «Для босяка немає традиції» [1, с. 112]. Як дотепно зазначав Уїльям Фолкнер, минуле ніколи не вмирає, воно навіть не є минулим. Про те, що минуле є надзвичайно складним предметом, зазначав і Йорн Рузен: «Дивно $з$ тим минулим. Воно минуло і все ж залишилось. Що сталося, те сталося, а ми ніяк із цим не миримось. Ми його усучаснюємо, тлумачимо, перетлумачуємо, освоюємо, відкидаємо, то відштовхуємо, то наближаємо, то обожнюємо, то паплюжимо, то матеріалізуємо, то розвіюємо. Ми його забуваємо, а воно все рівно не дає нам спокою» [17, с. 299].

Отже, історія і історична пам'ять є двома головними репрезентантами історичної свідомості. Історія прагне точно та об'єктивно дослідити минулі події. Історична пам'ять - більш народна, усна традиція, прив'язана до певного етносу, певної особи. Історія мусить бути одна, а варіантів історичної пам'яті безліч. Тим більше, що історія теж не є універсальною і єдиною. У кожного етносу своя історія. Історична пам'ять - це органічне поєднання минулого і сучасного (Йорн Рузен). Означене поєднання робить іii складним і суперечливим феноменом, але все ж таки реальним.

Історична пам'ять сягає ще глибин антропогенезу. Ці начала номінуються, з легкої руки К. Юнга, архетипами. Етнічна архетипічна пам'ять доповнює історичну, власне архаїчний контекст не може не впливати на історичну пам'ять наших сучасників. Існує зворотний зв'язок (вплив) історичної пам'яті на історію, яку досить активно залучають до політики. Архетипічний відбиток - одна 3 головних ознак етносу. За К. Юнгом, архетипи є продуктом підсвідомого і являють собою цілий світ, такий самий живий і реальний, як свідомість індивіда і навіть безмежно ширший та багат- 
ший [22, с. 6]. Колективне підсвідоме $є$ трансцендентним для людини, оскільки існує до і поза неї. «Свідомість цивілізованої людини - це частина психіки, яка надійно відокремилась від первинних інстинктів, які, загалом, нікуди не ділися. Вони лише втратили контакт зі свідомим і змушені нагадувати про себе обхідними шляхами (неврози, забудькуватість, обмовки, безвідповідальна поведінка)» [22, с. 40]. Він вважає, що сучасна людина позбавила себе засобів засвоєння допоміжних імпульсів, які містяться в інстинктах та підсвідомому. Більше того, К. Юнг переконаний, що мірою розвитку наук наш світ стає дедалі менш людським. Інтенсивно відбувається «психологічна інфляція» та втрата «Самості»- цілісності людської особи, яка потребує як свідомого, так і підсвідомого. Наш сучасник відчуває себе ізольованим у Космосі, його емоційна підсвідома єдність 3 природою втрачена. Архетип - це несвідома форма (образ), який не виникає 3 власного досвіду, він є генетичним спадком від предків. Загалом архетип визначається як спадковий фрагмент психіки, пов'язаний з інстинктами й історичною пам'яттю. Вони повторюються у кожному поколінні, збагачуючись за рахунок історичного досвіду.

Важливою підсистемою історичної пам'яті є пам'ять націіональна (етнічна). Осмислення цього феномена надзвичайно актуалізується в контексті складної і суперечливої проблеми національної ідентифікації, особливо в сьогоднішніх українських реаліях.

Останнім часом починають домінувати уявлення про націю, $\mathrm{i}$ навіть етнос, як феномен, що має переважно соціально-політичний, соціально-культурний характер. На цьому грунтувалася і «радянська теорія етносу». На Заході історично простежується тенденція ототожнення понять «нація»» та «народ», переміщення акцентів 3 «етнічного» на «політичне підданство». Йдеться про «постнаціональний» етап розвитку соціуму. Видається, щчо такий підхід робить сочіум штучним, авітальним творенням, полишеним власних природно-етнічних витоків.

Зауважимо, що концепцію постнаціонального етапу розвитку соціуму, нового космополітизму та «позаетнічності» посилюють прогресуючі процеси глобалізації світу. Вони стали предметом активного обговорення та аналізу вчених, політиків, представників 
світового істеблішменту i, зрештою, перспективним і цікавим об’єктом дослідження в галузі практичної філософії. Висновки та аналітичні матеріали, що з'являються в результаті такого обговорення, є здебільшого суперечливими, фрагментарними й непослідовними. Одні дослідники сподіваються, що глобалізація об’єднає все людство в єдину гармонійну систему, що нарешті дасть можливість розпочати продуктивне вирішення глобальних проблем сучасності. Інші переконані в тому, що цей процес призведе до подальшого загострення політичних, фінансовоекономічних, екологічних та інших проблем у планетарному масштабі. Одні кваліфікують їі як абсолютно й принципово нове явище в розвитку людської цивілізації, інші - як соціоприродне розгортання традиційних тенденцій розвитку людського соціуму. Глобалізація виявилась процесом складним, багатовекторним і достатньо непрозорим.

Сучасний світ одночасно постає як єдина цілісність, позаяк надзвичайно активно відбувається глобальна інтеграція господарських, технологічних та інформаційних структур, які дедалі більше стають транснаціональними, і як нагромадження надзвичайно різноманітних етно-державних утворень, що актуалізує пошук діалогу між самодостатніми і принципово різними державами, цивілізаціями та культурами. Якщо критично, без романтичного флеру, підійти до явища глобалізації, то можна дійти висновку, що дійсно нині в ньому домінують тенденції гегемонізму, завдяки чому воно $\epsilon$ вельми далеким від добровільного об'єднання народів в єдину світову систему. Часто-густо одна зі світових держав або їх соціально-політичне об'єднання (блок) видає себе за зразок ефективного соціально-політичного устрою і приклад для наслідування іншими. Інші, як менш досконалі й менш розвинені, мусять входити у «світовий контекст» за наперед і не ними визначеними правилами й відповідно до свого власного статусу. Нещодавно «нова історична спільність» - радянський народ видавалася як уособлення майбутнього всього світового співтовариства та успішне розв'язання «національного питання» в СРСР.

Ульріх Бек, спираючись на всепланетарний характер погіршення екологічної ситуації, рекомендує відмовитися від «методологічного націоналізму» в епоху космополітизації. Європейці лише 
роблять вигляд, що ще існують Німеччина, Франція, Італія тощо. Вони вже об'єднані в єдиний космополіс євро і спільними екологічними негараздами. «Індустріальні ризики й руйнування не зупиняються перед державними кордонами... Окремо взятій нації нічого робити $з$ наднаціональним розповсюдженням шкідливих речовин» [4, с. 47-48]. Але попри все це, французи, німці, італійці та інші європейці не сумніваються у своїй національній ідентичності.

Звичайно, поняття нації, особливо в цивілізаційному контексті, включає означені соціально-політичні й культурні аспекти, що $є$ визначальними характеристиками іiї як духовної спільноти. Усе це, безперечно, усвідомлюється у сфері політики та культури. Але звідки взялась нація як духовна спільнота? I чи вірно ми чинимо, коли виокремлюємо національне й етнічне? М. Бердяєв національне називав індивідуальним буттям, поза яким неможливе існування людства, проблемою історичною, а не соціальною. При цьому він вважав, що космополітизм є потворним і нездійсненним вираженням мрії про єдине, братське й досконале людство і, водночас, відкидав крайнощі «зоологічного націоналізму». Але був переконаним, що неможливо, щоб з лиця землі зникли «вирази національних облич, національних духовних типів і культур» [5, с. 13]. Людина виходить на загальнолюдський рівень через свою національну індивідуальність. «Можна й слід сподіватися, відзначав він, - зникнення класів та примусових держав у досконалому людстві, але не можна сподіватися зникнення національностей. Нація - це динамічна субстанція, а не минуща функція, i корінням своїм вона вростає у таємничу глибочинь життя» [6, с. 155].

Одну з цікавих спроб дістатися витоків етно-національного зробив свого часу Й. Гердер. Він досить аргументовано, спираючись на величезний історико-етнографічний матеріал, довів, що нація, національна культура топологічно пов'язані 3 природногеографічним середовищем. Тому держава, за Й. Гердером, є утворенням штучним, а нація - «природним органом людства». Саме звідси бере початок специфічний і неповторний «народний дух» (Volksgeist) - сукупність звичок і манер, спосіб почування й поведінки, властива кожному етносу опозиція «ми» й «вони», опо- 
зиція, яку аж ніяк не можна тлумачити лише як загрозу формуванню «загальнолюдських изінностей». Людство і нація не є альтернативними поняттями. Людство - це союз народів (націй). Але консолідація людства не заперечує національну чи культурну окремішність. Крім того, навіть у вже сформованому громадянському суспільстві, 3 його високим соціально-політичним рівнем, продовжує існувати національне (етнічне) життя, «охоплюючи ті аспекти життя людей певної етнічної приналежності, в яких домінують етнокультурні звичаєві стандарти, традиції, вірування, обрядовість, побут та ін.» [11, с. 99].

Нині спостерігаємо жваву дискусію щодо тлумачення поняття «нація» як феномена лише етнічного або лише політичного. Актуалізується проблема, «яким чином можна осучаснити і вдосконалити модель національної пам'яті українського народу? Щоб вона сприяла поглибленню української ідентичності і, разом 3 тим, враховувала толерантність європейського досвіду» [13, с. 157]. Л. Нагорна формулює три ознаки, властиві сучасній національній свідомості. Це: пасеїзм - надмірна увага до минулого; презентизм - осмислення минулого у річищі вимог сьогодення та футуризм пошук єднальних рамок між минулим і майбутнім. «Пасеїстичне спрямування історичного мислення починається 3 міфологізації праісторії, штучного заглиблення початків нації на тисячолітні відстані, пошуку на власній території «центрів етнос творення індоєвропейської раси». В українському варіанті це виявляється у твердженнях про виникнення на вітчизняній території людства, про трипільську культуру як початковий етап етногенезу українців, про Аратту як найдавнішу державу на планеті, про гуцульське походження Христа, про українську етнічну належність Атілли, локалізацію Трої на території сучасного Києва, тощо» [13, с. 163]. Так, не без цього. Цілком реальною $є$ і ситуація, коли надмірний «етноцентризм вправно маскується під патріотизм, груповий егоїзм і корпоративізм». Але все таки відкидати етнічний, або соціоприродний характер феномена нації і тлумачити ії лише як феномен соціальний або політичний видається некоректним. Поняття «представник нації» $\mathrm{i}$ «громадянин держави» не завжди збігаються. А «надмірна увага до минулого» є чинником скоріше позитивним, ніж негативним. Тут слід погодитися з М. Блюменкранцем, який застерігає, що 
«спокуса вирішувати життєво важливі проблеми сучасного буття виключно в соціологічній, політичній або економічній площині мені видаються хворобою нашого часу» [8, с. 168]. А також 3 М. Степико, який слушно стверджує: «Сьогоднішні спроби деяких авторів «позбавити» націю етнічних атрибутивних характеристик $\mathrm{i}$ звести їх тільки до сфери політики, на нашу думку, визначаються ототожненням шляхів формування нації на Заході $з$ феноменом нації взагалі як складним утворенням, яке має свої форми вияву в усіх сферах життя народу: економіці, політиці, соціальних та духовних відносинах» [21, с. 18]. Зведення феномена нації лише до сфери політики неминуче призводить до загострення протистояння етноцентризму та сучасних «вимог політкоректності». Л. Нагорна звертає увагу на зацикленості «на певній системі «своїх» цінностей і нерозумінні складних взаємозалежностей держав, народів, індивідів у світі, що глобалізується. Така оберненість у минуле, яка вибудовує україноцентричні пріоритети на сакралізації українських цінностей, постулатах власної непогрішності й задавлених претензіях до сусідів, формує ущербну свідомість і недієздатність, обеззброює людину перед складними викликами часу» [13, с. 33].

Інші автори, навпаки, звертають увагу на дефіцит сакралізації українських цінностей, «комплекс малоросійства» (С. Маланюк), «кочубеєвщину (Ю. Шевельов). Ю. Бадзьо вважає, що ситуація у сьогоднішніх українських реаліях $€$ загрозливою. «Населення державної території України, конгломерат, тобто механічне поєднання, етнічних груп, національностей, серед яких українці не мають власного правового, політико-культурного статусу, тобто перестають бути народом, суб'єктом правовідносин». В Україні домінує «українська політична нація», чим «усувається 3 ідеології історичного процесу національне значення етноніму, тобто знищується самий принцип національної самоідентифікації» [3, с. 9].

Микола Рябчук досліджує явище амбівалентності (дихотомії) сучасної української національної ідентичності: «українство» та «малоросійство». Спираючись на об'ємний матеріал конкретносоціологічних досліджень, він звертає увагу на надзвичайну складну ситуацію, що склалась у сучасній Україні з усвідомленням фе- 
номена національної ідентифікації іiі громадян. «Більшість українців 1990-х років була вже урбанізована й асимільована у совєтську версію російської культури і дистанціювала себе, психологічно і дискурсивно, від упослідженого сільського світу як уособлення злиднів відсталості та, метонімічно, всього українського. Вони вже встигли набути певної модерної ідентичності, яка була не етнічною чи громадянською, а насамперед державницькою, совєтською» [18, с. 9]. I до сьогодні дає себе знати вплив російсько-імперської та радянської спадщини. Більше того, і нині можна спостерігати вияви ставлення до всього етнічно українського «як до нижчого за якістю, гіршого за статусом і обмеженішим за вжитком» [18, с. 10]. Така амбівалентність сучасного українського соціуму є ситуацією надзвичайно небезпечною, яка провокує «розчепленість» в українському суспільстві, «спонукає безвідповідальних політиків використовувати цю розчепленість у своїх партикулярних маніпулятивних цілях. Вона дає зовнішнім ворогам додаткові можливості для підривної діяльності» $[18$, с. 6]. Наразі важливою проблемою є подолання цієї амбівалентності в українській національній свідомості і усвідомлення суті феномена адекватної історичної пам'яті у цьому контексті видається вельми продуктивним. Отже, некоректність і небезпека поділу і протиставлення націй на «політичні» та «етнічні»є очевидними. У світі не було і немає людської особи, яка була б позаетнічною (Л. Гумільов). Кожна людська особа так чи інакше несе в собі ознаки своєї етнічності. Без усвідомлення цього не має жодного сенсу вести мову про національну ідентифікацію.

Загалом проблема національної самоідентифікації набуває величезного значення в наш час, коли перед українським соціумом постала низка принципових питань, зокрема вибір стратегії подальшого розвитку формування самостійної політики і досягнення взаєморозуміння на міжнародній арені. 


\section{ЛITЕРАТУРА}

1. Архимандрит Рафаил (Карелин). Церковь и интеллигенция. Саратов : Изд-во саратовской эпархи, 2009. 320 с.

2. Ассман Аляйда. Простори спогаду. Форми та трансформації культурної пам'яті. Київ : Ніка-Центр, 2012. 437 с.

3. Бадзьо Юрій. Бойові генерали, сивоусі парубки з української вулиці і троянська кобила історичного процесу. Київ : Бібліотека політичної партії «Наша Україна», 2010. 152 с.

4. Бек У. Общество риска. На пути к другому модерну. Москва : Прогресс-Традиция, 2000. 384 с.

5. Бердяєв Ніколай. Національність і людство. Сучасність. 1993. № 1. С. 154-157.

6. Бердяев Н. А. Судьба России. Москва : Изд-во МГУ, 1990. 240 с.

7. Блок М. Апология истории или ремесло историка. Москва: Наука, 1986. 256 с.

8. Блюменкранц М. В поисках этики, или Археология зазеркалья. Письмо к немецкому другу. Вопросы философии. 2014. № 1. С. 166-170.

9. Булдаков В. П. Историк и миф. Перверсии современного исторического воображения. Вопросы философии. 2013. № 8. С. 54-64.

10. Гадамер Х.-Г. Истина и метод. Основы философской герменевтики. Москва : Прогресс, 1988. 704 с.

11. Кисельов М. М., Канак Ф. М. Національне буття серед екологічних реалій. Київ : Тандем, 2000. С. 91-116.

12. Колінгвуд, Робін Дж. Ідея історії. Київ : Основи, 1996. 615 с.

13. Нагорна Л. П. Історична культура: концепт, інформаційний ресурс, рефлексивний потенціал. Київ : ІП і ЕНД, 2014. 382 с.

14. Олик Джеффри. Фигурации памяти: процессо-реляционная методология, иллюстрируемая на примере Германии. Соииологическое обозрение. 2012. Т. 11. № 1. С. 40-74.

15. Плутарх. Избранные жизнеописания. Москва : Изд-во «Правда», 1990. T. $1.592 \mathrm{c}$.

16. Поппер Карл. Злиденність історицизму. Київ : Абрис, 1994. 192 с.

17. Рузен Й. Нові шляхи історичного мислення. Львів : Літопис, 2010. $358 \mathrm{c}$.

18. Рябчук Микола. Долання амбівалентності: Дихотомія української національної ідентичності. Історичні причини та політичні наслідки. Київ : ІПіЕНД ім. І. Ф. Кураса НАН України, 2019. 252 с.

19. Семенов Ю. И. Философия истории. (Общая теория, основные проблемы, идеи и концепции от древности до наших дней). Москва : Со- 
временные тетради, 2003. 2003. 776 с.

20. Тацит Конелий. Сочинения. В 2-х т. Санкт-Петербург : Наука, 1993. $736 \mathrm{c}$.

21. Українська політична нація: генеза, стан, перспективи. Київ : НІСД, 2004. 648 c.

22. Юнг Карл Густав. Человек и его символы. Москва : Серебряные нити, $1997.338 \mathrm{c.}$

23. Яковенко Наталя. Вступ до історії. Київ : Критика, 2007. 375 с.

24. Ясперс К. Смысл и назначение истории. Москва: Политиздат, 1991. $527 \mathrm{c}$.

\section{REFERECES}

Archimandrite Raphael (Karelin). (2009). Church and intelligentsia. Saratov : Publishing house of the Saratov diocese. 320 p. [In Russian].

Assman, Alida. (2012). Spaces of memory. Forms and transformations of cultural memory. Kyiv: Nica-Center. 437 p. [In Ukrainian].

Badzio, Yuri. (2010). Fighting generals, gray-haired guys from the Ukrainian street and Trojan mare of the historical process. Kyiv: Library of the political party “Our Ukraine”. 152 p. [In Ukrainian].

Beck, W. (2000). Risk Society. On the way to another modern. Moscow: Progress-Tradition. 384 p. [In Russian].

Berdyaev, Nikolai. (1993). Nationality and humanity. Modernity, N 1, p. 154157. [In Ukrainian].

Berdyaev, N. (1990). A The fate of Russia. Moscow: Publishing house MGU. 240 s. [In Russian].

Block, M. (1986). Apology of history or the craft of the historian. Moscow: Nauka. 256 s. [In Russian].

Blumenkrantz, M. (2014). In Search of Ethics, or The Archeology of the Mirror. Letter to a German friend. Voprosy filosofii (Questions of philosophy), № 1, 166-170. [In Russian].

Buldakov, V. P. (2013). Historian and myth. Perversions of the modern historical imagination. Voprosy filosofii (Questions of philosophy), № 8, 54-64. [In Russian].

Gadamer, H. G. (1988). Truth and method. Fundamentals of philosophy. hermeneutics. Moscow: Progress. 704 p. [In Russian]. 
Kiselyov, M. M., Kanak F. M. (2000). National existence among ecological realities. Kyiv: Tandem. P. 91-116. [In Ukrainian].

Collingwood, Robin J. (1996). The idea of history. Kyiv: Osnovy. 615 p. [In Ukrainian].

Nagornaya, L. P. (2014). Historical culture: concept, information resource, reflexive potential. Kyiv: SP and END. 382 p. [In Ukrainian].

Olic, Jeffrey. (2012). Memory figurations: process-relational methodology illustrated by the example of Germany. Sociological review. Vol. 11, № 1, p. 40-74. [In Russian].

Plutarch. (1990). Selected biographies. Moscow: Pravda Publishing House, Vol. 1. 592 p. [In Russian].

Popper, Carl. (1994). Poverty of historicism. Kyiv: Abtys. 192 p. [In Ukrainian].

Rusen, J. (2010). New ways of historical thinking. Lviv: Chronicle. 358 p. [In Ukrainian].

Ryabchuk, Mykola. (2019). Overcoming ambivalence: The Ukrainian dichotomy of national identity. Historical causes and political consequences. Kyiv: IPiEND. By name of I. F. Kuras NAS of Ukraine. 252 p. [In Ukrainian].

Semenov, Y. I. (2003). Philosophy of history. (General theory, basic problems, ideas and concepts from antiquity to the present day). Moscow: Sovremennyye tetradi. 776 p. [In Russian].

Tacitus, Conellius. (1993). Soch, in 2 vol. SPb.: Nauka. 736 p. [In Russian].

Ukrainian political nation: genesis, state, prospects. (2004). Kyiv: HICD. 648 p. [In Ukrainian].

Jung, Carl Gustav. (1997). Man and his symbols. Moscow: Serebryanyye niti. 338 p. [In Russian].

Yakovenko, Natalia. (2007). Introduction to history. Kyiv: Krytyka. 375 p. [In Ukrainian].

Jaspers, K. (1991). The meaning and purpose of history. Moscow: Politizdat. 527 p. [In Russian]. 


\title{
Mykola Kyselov
}

Doctor of Philosophical Sciences, Professor, leading researcher at the Gregory Skovoroda Institute of Philosophy National Academy of Sciences of Ukraine; Kyiv, Ukraine; e-mail:nn1942@ukr.net; ORCID: https://orcid.org/ 0000-0003-0427-1740

\section{History and historical memory: spheres of intersection}

\begin{abstract}
The article presents a comparative analysis of the phenomena of history and historical memory; the problem of limits of the historical method as a general scientific competence is analyzed. A retrospective is given the phenomenon of skepticism about the objectivity and validity of the conclusions of the historical science. Different forms of historical memory and their interactions are considered, which is recorded in modern historiography. The conclusion is being done that historical memory is a phenomenon that has deep roots in depths of anthropogenesis, in connection with which the teachings of K. Jung are affected about archetypes. There is a provision that there is feedback(interaction) of historical memory on history, which is quite active involved in politics. The archetypal imprint is one of the main features of the ethnicity. Archetypal origins of human memory, role of the historical memory in the formation of national identity, modifications and varieties of perception of the "historical past" are studied. The phenomenon of politicization of historical memory under the influence of ideological conjuncture are commented. The problem is extremely relevant now as today the political situation and the value system of the society are mostly determining the specifics of seeing, understanding and interpreting events of the past. Particular attention is paid to the term "national historical memory", a phenomenon that, together with history, is representing the historical consciousness. The provision of incorrectness of radical split of nations into "political" and "ethnic" is argued. Modern interpretations of the phenomena of ethnocentrism and presentism in the historical context. It is concluded that in general the problem of national self-identification is becoming enormous significance in our time, when the Ukrainian society raised a number of fundamental issues, in particular, the choice of strategy for the future development of the independent policy formation and achievement mutual understanding in the international arena.
\end{abstract}

Keywords: history, historical memory, self-identification, forms of the historical memory, presentism, ethnocentrism, self-identification, national politics. 